\title{
Starledger: A Business Activity Model Using SAP R/3 As A Classroom Tool To Measure Learning Outcomes
}

Joseph M. Ragan, Saint Joseph's University, USA

Zachary B. Leahan, Saint Joseph's University, USA

Robert G. Malonoski, Saint Joseph's University, USA

Christopher J. Savino, Saint Joseph's University, USA

\begin{abstract}
Integrating enterprise system applications within the accounting curriculum has been a major challenge for over eight years. Enterprise systems education is surprisingly well documented within the literature of enterprise system education. Not surprisingly, most of these papers provide a descriptive study of individual experiences of an institution of an academic unit. This paper focuses on the use of a practice case set within the accounting curriculum of a four year liberal arts based accounting program. The results of the integration of this practice case show the ability of enterprise software to bring textbook concepts to life and a high satisfaction level among the students using this package.
\end{abstract}

Keywords: ERP, Pedagogy, SAP, Business Process Model, Practice Case Set, Accounting

\section{INTRODUCTION}

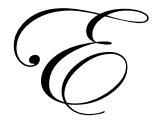

RP systems are generic, enterprise-wide software packages that provide comprehensive functionality and business process integration across the firm (Davenport, 1993). These enterprise-wide software systems offer significant potential benefits, as suggested by the growing scholarly literature that seeks to conceptualize and measure types of organizational outcomes, business impacts, and return on investment among ERP adopter firms (e.g. Hawking and Stein, 2004; Hitt et al., 2002 ; Hunton et al., 2003; Spathis and Constantinides, 2003). However, the scholarly and trade literature contains numerous accounts of the difficulties that firms face in justifying their decisions to implement integrated systems, in dealing with unanticipated side effects, and in learning to use these systems well enough to produce business value (Gattiker and Googhue, 2002; Granlund and Malmi, 2002; Hanseth et al., 2001; Kumar et al., 2003; and Oliver and Romm, 2002 ). The organizational learning curve is steep, and little is known about individual users' learning processes throughout the enterprise system adoption cycle. Unlike general computer skills, enterprise system user and management skills are not widely diffused in the working population. Firms express a great deal of frustration about the costs and modalities of learning to use ERP systems. Formal and informal training and learning process are constantly identified as critical success factors in mastery of ERP systems (Amoako-Gyampah, 2004; Esteves and Pastor, 2001; Umble et al., 2003).

Enterprise systems, the leader being SAP, form the core of the application infrastructure of most large companies. Teaching the concepts underlying an Enterprise System is an important but difficult task. Many students have very little business operating IT experience to which they can relate these concepts (Pierre-Majorique Léger, 2006). The most obvious learning need in the adoption of an ERP system is for end users to acquire operational capability with the software (Davis and Comeau, 2004).

Enterprise Resource systems are built around a business process model, which is a collection of activities that are designed to produce a certain output for a customer or user. Given the need of accounting practicioners to integrate international financial reporting standards, a curriculum enhanced with enterprise systems will help enable that. Stewart and Rosemann (2001) discuss an increased international collaboration at universities in order to 
deliver enterprise systems education. Tracy et al report an SAP funded initiative set up for the student marketplace. This initiative attempts to inculcate within student learners a sense of the business value chain and how ERP technologies can enable it.

The importance of ERP education has been recognized by many researchers including Watson and Schneider (1999). By incorporating ERP education into a curriculum, this allows students to interact first hand with an application that is used by companies all over the world. The ERP vendors argue that their products incorporate "world's best practice" for many of the business processes they support, making them an ideal teaching tool (Hawking, 2004; Watson and Schneider, 1999) while at the same time increasing the employment prospects of graduates (Hawking, McCarthy \& Stein, 2004). The integration of ERP into a curriculum provides the challenge of finding academic staff with ERP related skills. SAP, the leading ERP vendor, has established the largest ERP university alliance with more than 400 universities worldwide accessing their ERP system, SAP R/3.

Any ERP based exercise is inherently cross-functional, but in-depth ERP-based case studies are needed to fully realize the cross-functional integration potential of ERP (Johnson, Lorents, Morgan \& Ozmun, 2004). The choice and implementation of a specific case is related to three broad questions: is it relevant to the topic; is it substantive and complex enough to reflect a real situation; and is it stimulating enough to invoke discussion and subsequent learning (Hackney, McMaster and Harris, 2003).

This paper is organized as follows. We will first discuss the curricular framework around which this project is built. We then describe the course knowledge and skill requirement as well as the process and infrastructure needed to successfully implement this simulation. Finally, we explore the learning outcomes and student reactions to this project and offer suggestions to those who might consider integration of a simulation such as this into their courses.

\section{UNDERGRADUATE CURRICULUM INNOVATIONS}

Pedagogical revisions to the undergraduate curriculum in Accounting at the Haub School of Business encompass two broad categories. First, a newly created three-course sequence encompassing Intermediate and Advanced Accounting has been prepared. These courses are newly titled as FAIS I, II, and III. The three-course sequence focus is a single continuous learning experience, traversing sophomore to junior year. Each course will progressively build upon and expand the knowledge base acquired in the prior course. This knowledge base will include topical content in Accounting and application ability within SAP R/3. Second, another group of courses taught in the sophomore year incorporates subject matter inherent to cost and managerial accounting. These courses are titled MAIS I and II. The SAP exposure afforded students within these course sequences will provide hands on experiences in a team-oriented format within a business case context. It is envisioned that a single business case will be used throughout these five courses.

\section{COLLABORATIVE LEARNING MODEL (STAR SCHOLARS)}

A unique feature of the course pedagogy is the utilization of STAR Scholars to assist in development and delivery of various SAP scenarios. These scholars are chosen through a highly selective process and specially trained to deal with these application scenarios. To date, there are nine active STAR Scholars, comprised mostly of junior and senior Accounting majors. These students are compensated for the work done in class and are provided with enrichment activities, such as field visits and special speakers, helping them to understand the essentiality of implementation of state of the art software. They often participate in research-based projects designed and developed by faculty. In addition, STAR Scholars involve themselves in a series of special activities under the direction of a faculty mentor. Developing scenarios of various computer applications involving Enterprise Resource Planning software and SAP are included. In addition, seminars with entrepreneurs and technology leaders to provide opportunities to interact on a personal and informal level are held with business leaders. Sponsored participation in special events with alumni working in technology and consulting fields is also a component. These students assist in classroom delivery and continue to service the course by maintaining a help desk for students. 


\section{PHASES OF THE CURRICULUM ROLLOUT}

The courses are three-credit courses required for all accounting majors, typically in the sophomore and junior years. SJU requires all students to have laptops. A typical class consists of 24 students and is taught over a fourteen-week semester. The university is a member of the SAP Alliance. As a member of the University Alliance, SJU is given access to SAP R/3 in real time (24/7) through the University of Wisconsin at Milwaukee. A major objective of the university alliance is the ongoing development of academic scripts to be used to teach accounting within the SAP R/3 system. These scripts are available by accessing SAP and its innovation watch. The practice set that we used was developed at Cal State Chico by Dr. James Mensching. Dr. Mensching is a leading developer in accounting information systems material. This material is readily transferable to the classroom and is an excellent platform from which to use SAP R/3.

In our most recent case study on Cottonwood Distribution, Inc., the students review general accounting principles and procedures. In the first part of the assignment, they create general journal entries for a series of transactions. The second part of the assignment continues the review of accounting procedures with additional journal entries and the adjusting journal entries for month end close. Lastly, the students explore how their journal entries might be created in an automated system by entering their "manual" journal entries in the system. Then they generate an account balance ledger report to see the effect of their work (Appendix A). If students are unfamiliar or forget how to navigate through SAP, they could watch a remedial video that was given to all students on a CDROM. After students have completed the journal entries, they are taken through a series of steps to look at the balance sheet and profit and loss statement. These case studies are of significant importance since it integrates and reinforces accounting concepts, SAP, and has the look and feel of a student working in the real world. SAP reports generated by the practice set are provided in Appendix B.

\section{ASSESSMENT OF LEARNING}

When students first enter the classroom and hear that they will be involved with SAP and enterprise resource planning, they usually wonder, "What is this SAP system and how will this ever help me in the future as an accountant?" When students are approached with something new, especially technology, there is usually a feeling of uncertainty and worry.

Integrating SAP ERP into the curriculum gives the students a change of scenery in the classroom. The enthusiasm of learning SAP can be displayed through the results of a survey for STARLedger, which was given to students at the end of the semester. This survey captures the students' view on the STARLedger case study and its relationship to accounting and enterprise systems.

The survey results show us that about $79 \%$ of the students thought that the STARLedger case study was challenging. Although challenging, it was delivered in a way that supplemented the students' understanding of enterprise system concepts and financial accounting systems, with $55 \%$ and $27 \%$ of the class agreeing and strongly agreeing, respectively. Over $70 \%$ of the students feel that because of the competency exam, they have a better understanding of the relationship between enterprise resource systems and financial accounting. Aside from the competency exam, students were also given SAP homework assignments, which $82 \%$ of the students agreed that it helped them to make evaluations and judgments about business process functions and activities. SAP homework assignments involved students doing different things within SAP and then answering a few questions about what they encountered and learned. It is also important to note that $91 \%$ of the students agree that the STARLedger case study is a useful project and should be continued in the Financial Accounting Systems Class. When students were asked which module they enjoyed most, the highest percentage of $43 \%$ said Strategic Enterprise Management. We feel that most students enjoyed this best because it allows for more freedom and exploring on their own, rather than following direct steps. Lastly, the module that students least enjoyed was Purchasing. On the contrary to Strategic Enterprise Management, the Purchasing module is very mechanical and does not allow for any freedom for the students. This makes it for a much less entertaining area of SAP to complete.

At the end of the survey, students were allowed to enter their own comments about the class. One student commented, "I thought Module 5, the data warehouse, was by far the most interesting out of the group. I really 
thought it was the most useful because we weren't just going through and clicking what the packet says to. In Module 5, we were told what to go into, and from there we were able to be creative and give our input on how the company looks from our perspective." Another students says, "The supplemental videos are very helpful for Modules 3 through 5, especially 5 because I was not experienced with the business warehouse." Someone else states, "It was helpful in not only performing the motions, but understanding the reasoning behind them." "Keep the SAP program around. It is interesting and it's nice to not always have homework that is from the textbook." Lastly, a student remarked, "I think SAP is one of the best things to happen to the Accounting Program at Saint Joseph's University. Not many students can leave college with a comprehensive overview of such difficult and important R/3 accounting software."

We can see that the survey results and comments previously mentioned affirm the students' outlook of SAP and enterprise resource systems, validating that they are an integral part to the accounting curriculum along with an invaluable learning experience, which they can use to their advantage after graduation.

\section{AUTHOR INFORMATION}

Joseph M. Ragan, Professor Ragan is Professor and Chair of the Department of Accounting at Saint Joseph's University. He is also the founder of the Philadelphia Consulting Group and has served as a systems consultant to a number of Fortune 500 companies. His research is at the intersection of financial accounting and information systems. His interests include examining the business value of information technology. He currently serves on the board of educational advisors of SAP Americas.

Zachary B. Leahan, Zach is a recently graduated accounting major from Saint Joseph's University. He has been working with SAP as a STAR Scholar at Saint Joseph's University since his freshman year. He has completed two summer internships with SAP Americas in Newtown Square, PA. He accepted a full time position as a Systems \& Process Assurance Associate with PricewaterhouseCoopers in Philadelphia.

Robert G. Malonoski, Robert recently graduated from Saint Joseph's University where he was an accounting \& finance major. While at Saint Joseph's, he had the opportunity to perform in-class implementation of SAP and research on accounting information systems as a STAR Scholar. Additionally, he completed two summer internships with a local accounting firm. He will be starting his career as an Associate in the Assurance line of service for PricewaterhouseCoopers in Philadelphia.

Christopher J. Savino, Chris is a senior accounting and finance student at Saint Joseph's University. He currently serves as the managing partner of the STAR Scholars program at Saint Joseph's University. Following both his sophomore and junior years, he interned with PricewaterhouseCoopers, in Jersey City, NJ and Philadelphia, PA, respectively. He is seeking a full-time position in PricewaterhouseCoopers' Systems \& Process Assurance practice in Philadelphia, PA following graduation in May 2010.

\section{BIBLIOGRAPHY}

1. Amoako-Gyampah, Kwasi (2004 "ERP Implementation Factors: a Comparison of Managerial and EndUser Perspectives.” Business Process Management Journal, Vol. 10, No. 2, pp. 171-183.

2. Antonucci, Yvonne L., and Michael zur Muehlen (2001 "Deployment of Business to Business Scenarios in ERP Education: Evaluation and Experiences from an International Collaboration." Proceedings of the Seventh Americas Conference on Information Systems, Boston, pp. 998-1004.

3. Bailey, A., C. Chow, and K. Haddad (1999 "Continuous Improvement in Business Education: Insights from the For-Profit sector and Business School Deans." Journal of Education for Business. Vol. 74. No. 3, pp. 165-181.

4. Bendoly, E. (2005 "Revamping ERP Coursework: New Priorities in Practice, New Priorities in Education", Innovation Monograph, November, pp. 81-88.

5. Bingi, P., Sharma, M., and Godla, J. (1999 "Critical Factors Affecting an ERP Implementation", Information Systems Management, Vol. 16, No. 3, pp. 7-16. 
6. Boudreau, M., and Robey, D. (1999 "Organizational Transition to Enterprise Resource Planning Systems: Theoretical Choices for Process Research", Proceedings of the International Conference on Information Systems, Charlotte, NC, pp. 291-299.

7. Boykin, R.F., and Martz, J.W.B. (2004 "The Integration of ERP into a Logistics Curriculum: Applying a System Approach", Journal of Enterprise Information Management, Vol. 17, No. 1, pp. 45-55.

8. Boyle, T.A., and Strong, S.E. (2006 "Skill Requirements of ERP Graduates", Journal of Information Systems Education, Vol. 17, No. 4, pp. 403-412.

9. Comeau. Jana and Davis, Charles H., Enterprise Integration in Business Education: Design and Outcomes of a Capstone ERP-based Undergraduate e-Business Management

10. Davenport, T. (1993 Process Innovation: Reengineering Work through Information Technology, Harvard School Press: Boston.

11. Davis, C., and Comeau, J. (2004 "Enterprise Integration in Business Education: Design and Outcomes of a Capstone ERP-based Undergraduate e-Business Management Course", Journal of Information Systems Education, Vol. 15, No. 3, pp. 287-299.

12. Dolphin Group (2002). SAP Consulting and Education (2002): Dolphin 200 - Configuration and Integration Workshop. Self-published.

13. Draijer, C., and Schenk, D. (2004 "Best Practices of Business Simulation with SAP R/3", Journal of Information Systems Education, Vol. 15, No. 3, pp. 261-265.

14. Esteves, Jose, and Joan Pastor (2001 "Analysis of Critical Success Factors Relevance of along SAP Implementation Phases." Proceedings of the Seventh Americas Conference on Information Systems, Miami, 2001, pp. 1019-1025.

15. Esteves, J., Pastor, J., and Casanovas, J. (2002 "Monitoring Business Process Redesign in ERP Implementation Projects", Proceedings of the Americas Conference on Information Systems (AMCIS Dallas, TX.

16. Gattiker, Thomas F., and Dale L. Goodhue (2002 "Software-Driven Changes to Business Processes: an Empirical Study of Impacts of Enterprise Resource Planning (ERP) Systems at the Local Level." International Journal of Production Research, Vol. 40, No. 18, pp. 4799-4814.

17. Granland, Markus, and Teemu Malmi (2002 "Moderate Impact of ERPS on Management Accounting: a Lag or Permanent Outcome?" Management Accounting Research, Vol. 13, pp. 299-321.

18. Hanseth, Ole, Cluadio U. Ciborra, Kristin Braa (2001 "The Control Devolution: ERP and the Side Effects of Globalization," The Data Base for Advances in Information Systems, Vol. 32, No. 4, pp. 34-48.

19. Hackney, R., McMaster, T., and Harris, A. (2003 "Using Cases as a Teaching Tool in IS Education", Journal of Information Systems Education, Vol. 14, No. 3, pp. 229-234.

20. Hadaya, Pierre and Pellerin, Robert, Proposing a New Framework and an Innovative Approach to Teaching Reengineering and ERP Implementation Concepts

21. Harmon, P. (2003 Business Process Change: A Manager's Guide to Improving, Redesigning, and Automating Processes, Morgan Kaufmann Publishers: San Francisco.

22. Harrington, H.J. (1991 Business Process Improvement, McGraw-Hill: New York.Hawkins, P., McCarthy, B., and Stein, A. (2004 "Second Wave ERP Education", Journal of Information Systems Education, Vol. 15, No. 3, pp. 327-332.

23. Haynen, R., Holmes, M., and Cappel, J. (2000 "A Framework for SAP R/3 Enterprise Software Instruction", The Journal of Computer Information Systems, Vol. 40, No. 2, pp. 79-85.

24. Hawking, Paul, and Andrew Stein (2004 "Revisiting ERP Systems: Benefit Realization." Proceedings of the $37^{\text {th }}$ Hawaii International Conference on Systems Science, Maui.

25. Hitt, Loren M., D.J. Wu, Xiaoge Zhou (2002 "Investment in Enterprise Resource Planning: Business Impact and Productivity Measures." Journal of Management Information Systems, Vol. 19, No. 1, pp.7198

26. Holland, C., Light, B., and Gibson, N. (1999 "A Critical Success Factors Model for Enterprise Resource Planning Implementation", Proceedings of the European Conference on Information Systems, Copenhagen, pp. 273-279.

27. Hunton, James E., Barbara Lippincott, and Jacqueline L. Reck (2003 "Enterprise Resource Planning Systems: Comparing Performance of Adopters and Non Adopters." International Journal of Accounting Information Systems, Vol. 4, pp. 165-184 
28. Johnson, T., Lorents, A., Morgan, J., and Ozmun, J. (2004 "A Customized ERP/SAP Model for Business Curriculum Integration", Journal of Information Systems Education, Vol. 15, No. 3, pp. 245-253.

29. Kettinger, W., Teng, J., and Guha, S. (1997 "Business Process Change: A Study of Methodologies, Techniques, and Tools", MIS Quarterly, Vol. 21, No. 1, pp. 55-80

30. Kumar, Vinod, Bharat Maheshwari, and Uma Kumar (2003 “An Investigation of Critical Management Issues in ERP Implementation: Empirical Evidence from Canadian Organizations.” Technovation, Vol. 23, pp. 793-807.

31. Léger, P.M. (2006 "Using a Simulation Game Approach to Teach Enterprise Resource Planning Concepts", Journal of Information Systems Education, Vol. 17, No. 4, pp. 441-448.

32. Meta Group (2003 Gaining Continuous Value from ERP through a Comprehensive, Continuous Education Strategy. Stamford, Conn.: white paper.

33. Morrell, J.S., Freeman, J.L., Serrano, F., and Mock, R. (1993 "Hands-On Experience for Students in Information Systems Design", Journal of Applied Business Research, Vol. 9, No. 4, pp. 141-145.

34. Mustoe, L.R., and Croft, A.C. (1999 "Motivating Engineering Students by Using Modern case Studies", European Journal of Engineering Education, Vol. 15, No. 6, pp. 469-476.

35. Nah, F., Lau, J., and Kuang, J. (2001 "Critical Factors for successful Implementation of Enterprise Systems", Business Process Management Journal, Vol. 7, No. 3, pp. 285-296.

36. Nelson, Robert J., and Ido Millet (2001 "A Foundation Course in ERP and Business Processes: Rationale, Design, and Educational Outcomes." Proceedings of the Seventh Americas Conference on Information Systems, Miami, pp. 992-997.

37. Oliver, Dave, and Celia Romm (2002 “Justifying Enterprise Resource Planning Adoption,” Journal of Information Technology, Vol. 17, pp. 199-213.

38. Peslak, A. (2005 "A Twelve-Step Multiple Course Approach to Teaching Enterprise Resource Planning", Journal of Information Systems Education, Vol. 16, No. 2, pp. 147-155.

39. Porter, L. and L. McKibbin (1998 Management Education and Development: Drift or Thrust into the 21st Century, McGraw-Hill, New York, NY.

40. Rosemann, Michael, and Ed Watson (2001 "Education in Enterprise Systems at Universities," Proceedings of the Seventh Americas Conference on Information Systems, Boston, pp. 2244-2248.

41. Scott, Judy E (1999 "ERP Effectiveness in the Classroom: Assessing Congruence with Theoretical Learning Models." Proceedings of the Fifth Americas Conference on Information Systems, Madison, pp. 794-796.

42. Spathis, Charalambos and Sylvia Constantinides (2003 “The Usefulness of ERP Systems for Effective Management." Industrial Management and Data Systems Vol. 103, No. 9, pp. 677-685

43. Stewart, G., and Rosemann, M. (2001 "Industry-Oriented Design of ERP-Related Curriculum - An Australian Initiative", Business Process Management Journal, Vol. 7, No. 3, pp. 234-242.

44. Stewart, Glenn, Stephen Tracy, Ray Boykin, Majdi Najm, Michael Rosemann, Luiz Carpinetti, and Ed Watson (2002 "Configuring the SAP Student Marketplace for the Advancement of Research and Teaching (SAP SMART)." Proceedings of the Eighth Americas Conference on Information Systems, Dallas, pp. 918924.

45. Umble, Elizabeth J., Ronald R. Haft, and M. Michael Umble (2003 "Enterprise Resource Planning: Implementation Procedures and Critical Success Factors.” European Journal of Operational Research 146, pp.241-257.

46. Wagner, William P., Mohammad K. Najdawi, and James Otto (2000 "An Empirical Investigation into the Impact of ERP Training on Cross Functional Education." Journal of Business Education, Vol. 1, paper No. 107.

47. Watson, Edward F., and Helmut Schneider (1999 "Using ERP Systems in Education." Communications of the Association for Information Systems Vol. 1, Article 9.

48. Wheatley, Malcolm (2000 "ERP Training Stinks," CIO Magazine, June 


\section{Appendix A}

Balance Sheet Accounts

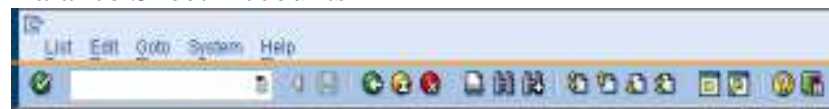

DED GAP

G/L Account Balances

Cottoneotd 015t. 858

Fied Blatt

6.4 Necount falances

Tief 12.20 B tats 0539612609 -

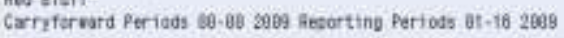

Recstrobiruster Pape

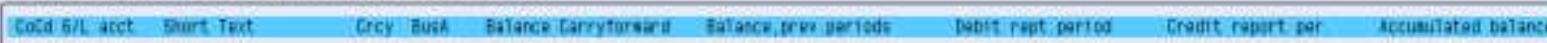

\begin{tabular}{|c|c|c|c|c|c|c|c|}
\hline 28281601 & cast - B of A & USD & e. $x$ & 8.20 & $429,242,00$ & 171.458 .00 & $257,745.08$ \\
\hline 88281101 & Accounts pacalvable & UED & 0.06 & 0.60 & $397,568,00$ & $272,7 \in \theta .9 \theta$ & 44,690099 \\
\hline 86281111 & Mtlsasnte for toabtr & USO & 0.60 & 0.00 & $3,500.00$ & 8,61800 & $3,11800$. \\
\hline geว8 1281 & Pasale Narchand1an & 450 & B. 18 & e. 60 & 185,921 เ6 & 75,144 , 60 & 110,577 as \\
\hline 80281202 & Evest Herchimilise & 1560 & 0.00 & 0.60 & 250.122 .00 & $104,627.09$ & $145,425,00$ \\
\hline 98281381 & Dttice supplies & USD & का & $\pi=80$ & 354 en & $5: 4.00$ & 45808 \\
\hline 90201382 & Presaia lnairace & $U \omega$ & 0.00 & 8.60 & $4,800,00$ & 500.08 & $4,498.08$ \\
\hline 88281383 & Fregand Aent & U\$D & Q. 89 & 6.66 & $18,808 \mathrm{8B}$ & 898 & $10,898.88$ \\
\hline 90281304 & Presasd Alvertioing & Uso & $\theta .00$ & 0.60 & $13,200: 90$ & 090 & $13,290.05$ \\
\hline 80281481 & Uarzhouse and uttice & uso & 6. 010 & 0.60 & $102,000,00$ & 0.80 & 182,06008 \\
\hline 90281411 & Mess segrtec13 - Equi & USO & 600 & 0.60 & 0.60 & $22,500.00$ & $32,500.08$. \\
\hline 88282501 & Accoumts Payable & UsD & e. $\infty$ & 8.80 & $114,412,80$ & 198.524 .80 & $76,112,08$ \\
\hline 80282602 & Necrued Unes Payati & USO & 8.06 & 6.60 & $20,400.00$ & 42,05000 & $21,690,00$. \\
\hline 38282644 & Nccrued Sales far & บฐD & E. 6 & 9.60 & Q08 & 4.178 & $4,178.98$ \\
\hline 80282038 & Darrent Mationties o & USO & B. 00 & 9.60 & 6.60 & $11,206,00$ & $11,206.08$ \\
\hline 88282695 & Other Atcrued expets & USO & a. 01 & 3.60 & $2,539.68$ & $5,261.08$ & 2,603 as \\
\hline 96282105 & Wates Payphlas. & USD & 80 & 0.60 & 860 & $50,394,80$ & $58,334.08$ \\
\hline 98283605 & Canson Stock + na pa & uso & 8.98 & 6.60 & 8.88 & $2 \pm 0,0 \pm 0$. & $200,698.05$ \\
\hline 98283198 & Patainad Earnings & 450 】 & 0.00 & 0.60 & 8.00 & $230,200.00$ & $290,250.00$ \\
\hline
\end{tabular}

Screenshot 1.

Income Statement Accounts \& Trial Balance

\begin{tabular}{|c|c|c|c|c|c|c|}
\hline 90284001 & 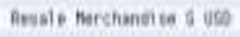 & 000 & 000 & 0.08 & $119,100.05$ & $119,100.00$ \\
\hline 4028 460ะ & Event Herchavdise L 4 uth & 0. 0 - & B 00 & 0.08 & 167,94002 & $167,000.05$ \\
\hline 10204906 & Purchane bistoint UtS & 0.06 & 0.00 & 0.05 & $1,040.08$ & $1,040,05$ \\
\hline 30285601 & Cent of foads told . UES & 006 & 800 & 75,144 as & 86 & 75,144 b5 \\
\hline 90205602 & Cont of Gesds bold . UES & 0.00 & a. 00 & $104,697,00$ & 0. 02 & 504,69705 \\
\hline งอ2ล & Deurectation axpense ute & 0 of & 000 & 92008 & 00 & $90 \mathrm{~m}$ \\
\hline 10286003 & Inarince fyethe Ues & 000 & 0.00 & 600.00 & 0.00 & 400.05 \\
\hline 1028 6อง & office tupelias txpe use & 000 & 000 & 51408 & 6. 68 & 51408 \\
\hline $1020600 \%$ & Sol ar ieb/vages Espen UCS & 000 & 0.00 & $42,640,00$ & 0. 01 & $42,600,00$ \\
\hline 3028 6เ06 & 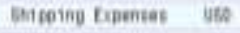 & a 08 & in at & 2: 1320 as & in & 2,00008 \\
\hline $10: 06000$ & Utilities fosense & 006 & 000 & $2,689.02$ & 0.04 & 2,669010 \\
\hline taze 6051 & Bes Detit Dopense & 000 & 800 & $1,2 a+$ at & 80 & $1, \mathrm{ar}: \mathrm{B}$ \\
\hline '9020 & ves & 0.06 & 000 & $1,745,673.06$ & $1,745,672.02$ & 0. $6 n$ \\
\hline
\end{tabular}

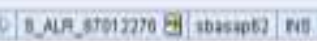

Screenshot 2 . 


\section{Appendix B}

\begin{tabular}{|c|c|c|c|c|}
\hline \multicolumn{5}{|c|}{$\begin{array}{c}\text { Cottonwood Distribution, Inc. } \\
\text { Balance Sheet }\end{array}$} \\
\hline \multicolumn{5}{|c|}{ Assets } \\
\hline \multicolumn{5}{|l|}{ Current Assets: } \\
\hline Cash & & $257,745.00$ & & \\
\hline Accounts Receivable & $44,800.00$ & & & \\
\hline Allowance for doubtful accounts & $3,118.00$ & $41,682.00$ & & \\
\hline Resale Merchandise Inventory & & $110,677.00$ & & \\
\hline Event Merchandise Inventory & & $145,425.00$ & & \\
\hline Office Supplies & & 450.00 & & \\
\hline Prepaid Insurance & & $4,400.00$ & & \\
\hline Prepaid Rent & & $10,000.00$ & & \\
\hline Prepaid Advertising & & $13,200.00$ & & \\
\hline Total Current Assets & & & \multicolumn{2}{|r|}{$583,579.00$} \\
\hline \multicolumn{5}{|l|}{ Non-Current Assets: } \\
\hline Warehouse and Office Equipment & $162,000.00$ & & & \\
\hline Accumulated depreciation - Equipment & $22,500.00$ & & & \\
\hline Total Non-Current Assets & & & & $139,500.00$ \\
\hline Total Assets & & & $\$$ & $723,079.00$ \\
\hline \multicolumn{5}{|c|}{ Liabilities \& Stockholders' Equity } \\
\hline \multicolumn{5}{|l|}{ Current Liabilities: } \\
\hline Accounts Payable & & $76,112.00$ & & \\
\hline Accrued Sales Tax Payable & & $4,178.00$ & & \\
\hline Accrued Wages Payable & & $21,600.00$ & & \\
\hline Current Maturities of LT Debt & & $11,206.00$ & & \\
\hline Other Accrued Expenses Payable & & $2,663.00$ & & \\
\hline Total Current Liabilities & & & & $115,759.00$ \\
\hline \multicolumn{5}{|l|}{ Long-Term Liabilities: } \\
\hline Notes Payables & & $59,334.00$ & & \\
\hline Total Long-Term Liabilities & & & & $59,334.00$ \\
\hline Total Liabilities & & & & $175,093.00$ \\
\hline \multicolumn{5}{|l|}{ Stockholders' Equity: } \\
\hline Common Stock - (no par) & & $200,000.00$ & & \\
\hline Retained Earnings & & $347,986.00$ & & \\
\hline Total Stockholders' Equity & & & & $547,986.00$ \\
\hline Total Liabilities \& Stockholders' Equity & & & $\$$ & $723,079.00$ \\
\hline
\end{tabular}

Table 1 
Cottonwood Distribution, Inc. Income Statement

\begin{tabular}{|c|c|c|}
\hline \\
\hline & Amount & $\begin{array}{c}\text { Percentage of } \\
\text { Total Net Revenue }\end{array}$ \\
\hline Resale Merchandise Sales & $119,100.00$ & \\
\hline Event Merchandise Sales & $167,960.00$ & \\
\hline Net Revenue & $287,060.00$ & $100 \%$ \\
\hline Cost of Goods Sold - Resale Merchandise & $75,144.00$ & $26 \%$ \\
\hline Cost of Goods Sold - Event Merchandise & $104,697.00$ & $36 \%$ \\
\hline Purchase Discount & $(1,840.00)$ & $-1 \%$ \\
\hline Net Cost of Goods Sold & $178,001.00$ & $62 \%$ \\
\hline Gross Profit & $\$ 109,059.00$ & $38 \%$ \\
\hline \multicolumn{3}{|l|}{ Operating Expenses: } \\
\hline Depreciation expense & 900.00 & $0.31 \%$ \\
\hline Insurance Expense & 400.00 & $0.14 \%$ \\
\hline Office Supplies Expense & 514.00 & $0.18 \%$ \\
\hline Salaries/Wages Expense & $42,600.00$ & $14.84 \%$ \\
\hline Shipping Expenses & $2,899.00$ & $1.01 \%$ \\
\hline Utilities Expense & $2,663.00$ & $0.93 \%$ \\
\hline Bad Debt Expense & $1,297.00$ & $0.45 \%$ \\
\hline Total Operating Expenses & $51,273.00$ & $18 \%$ \\
\hline Net Income & $\$ 57,786.00$ & $20 \%$ \\
\hline
\end{tabular}

Table 2 


\section{Appendix C}

STARLedger Survey Report

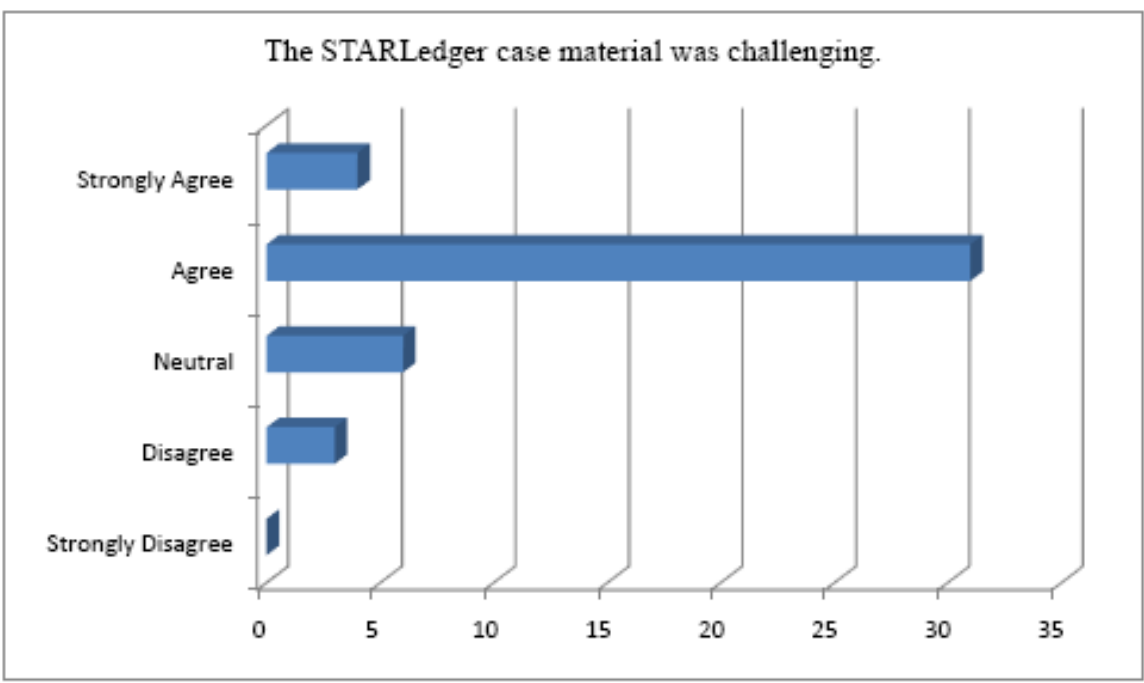

Chart 1.

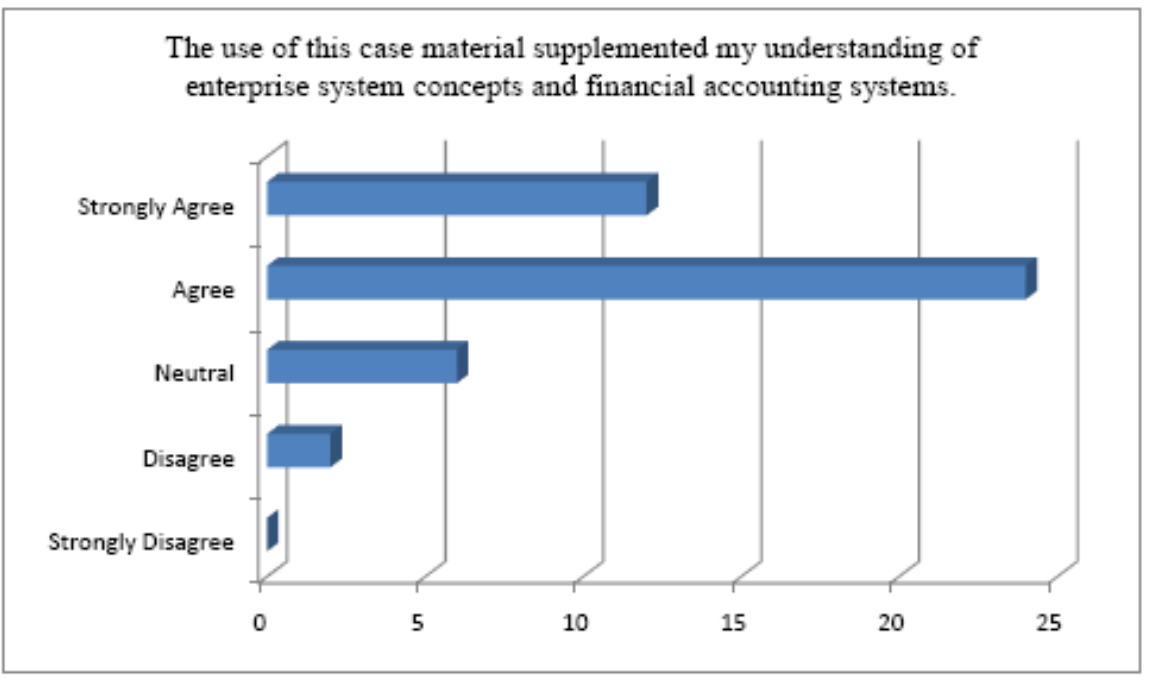

Chart 2. 


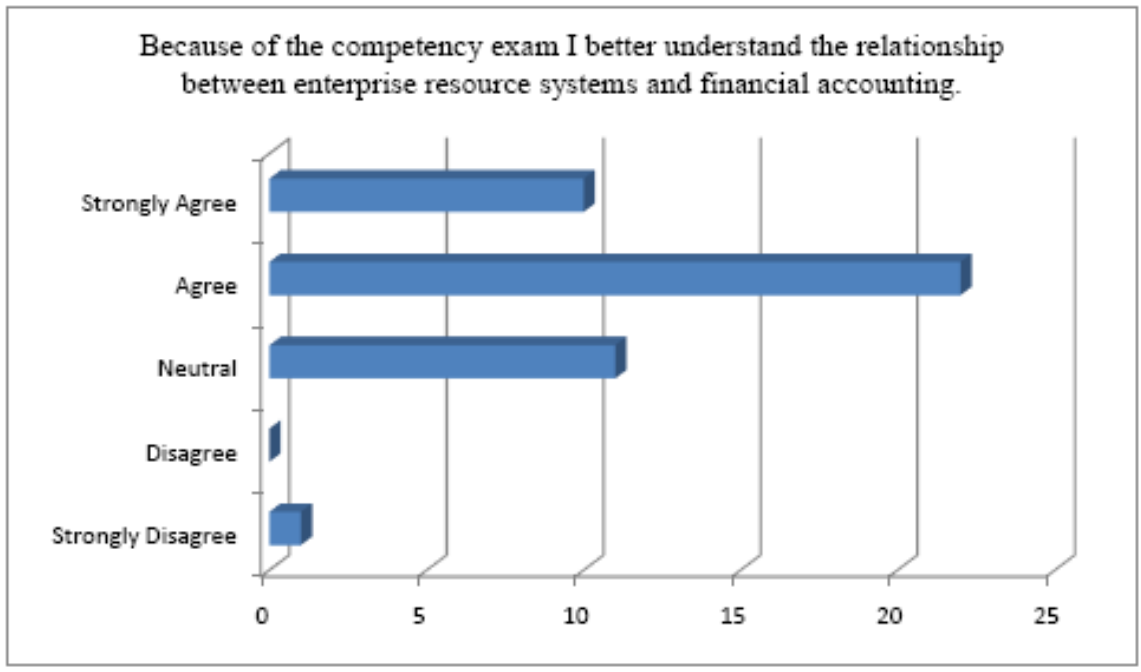

Chart 3.

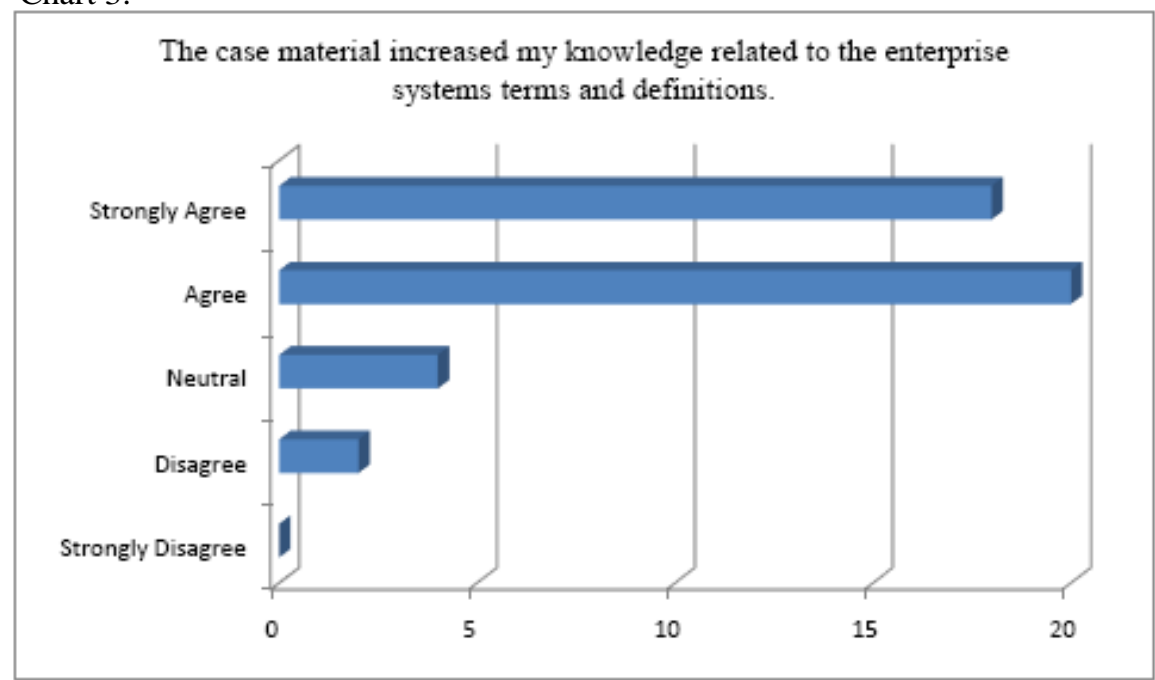

Chart 4.

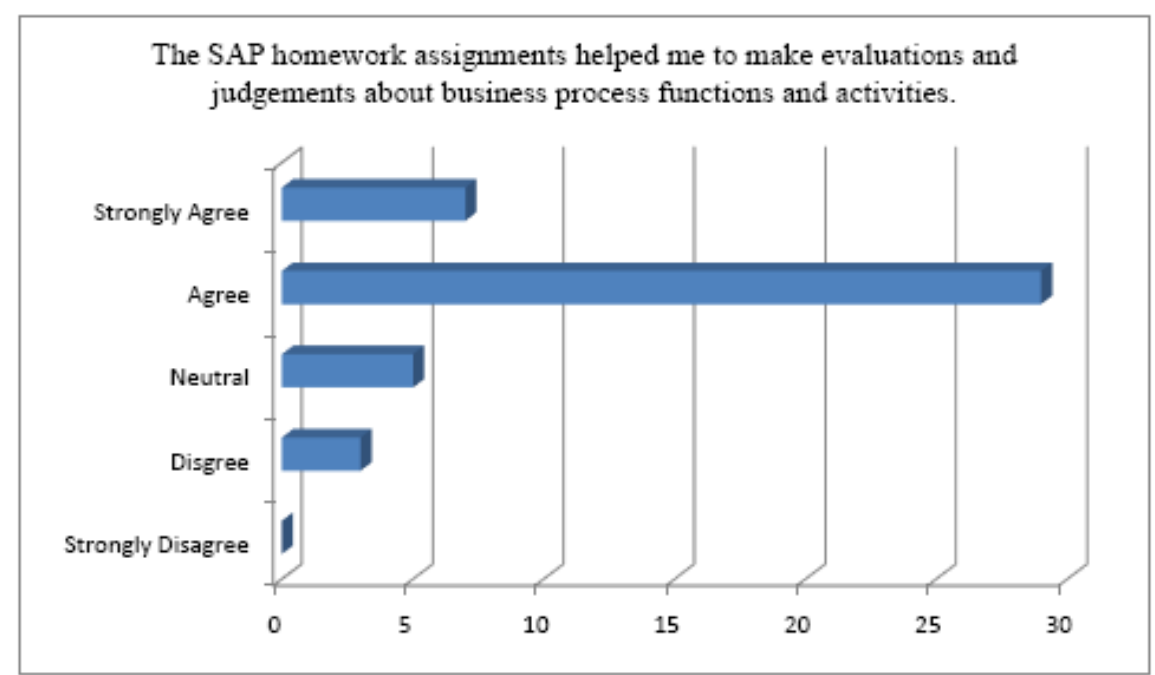

Chart 5. 


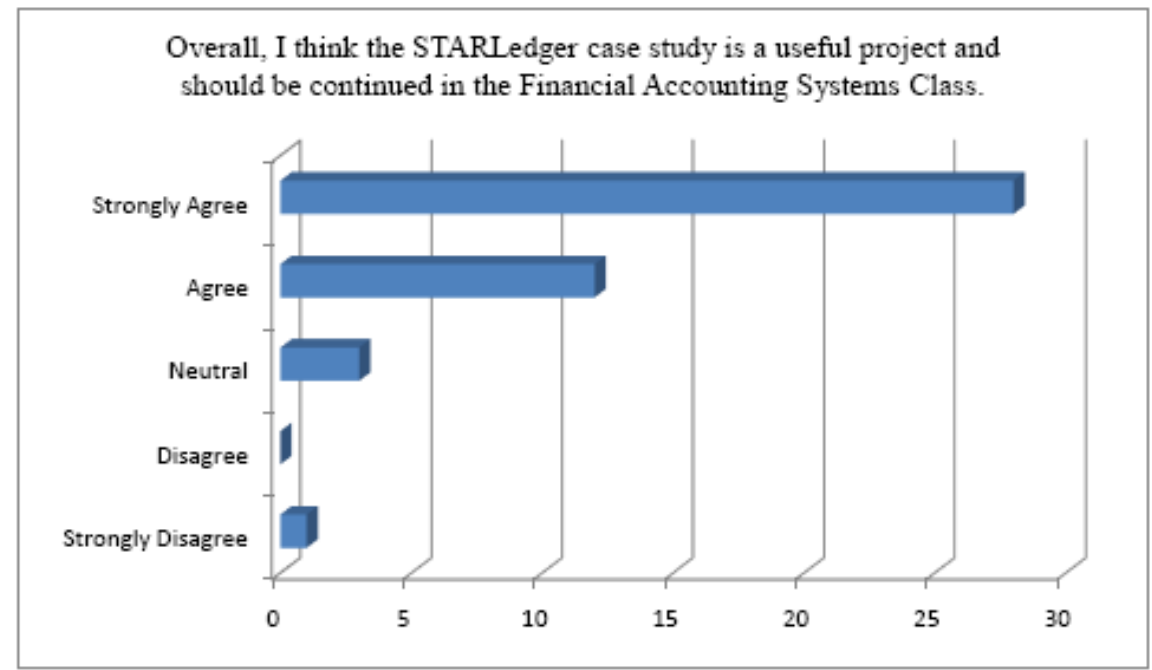

Chart 6.

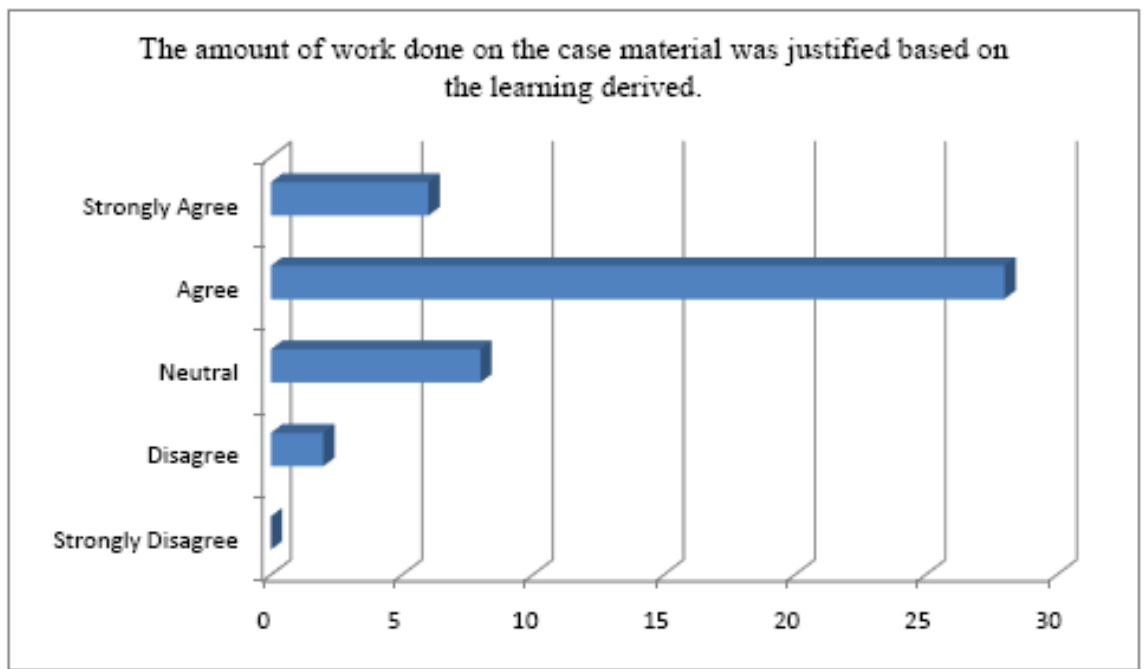

Chart 7.

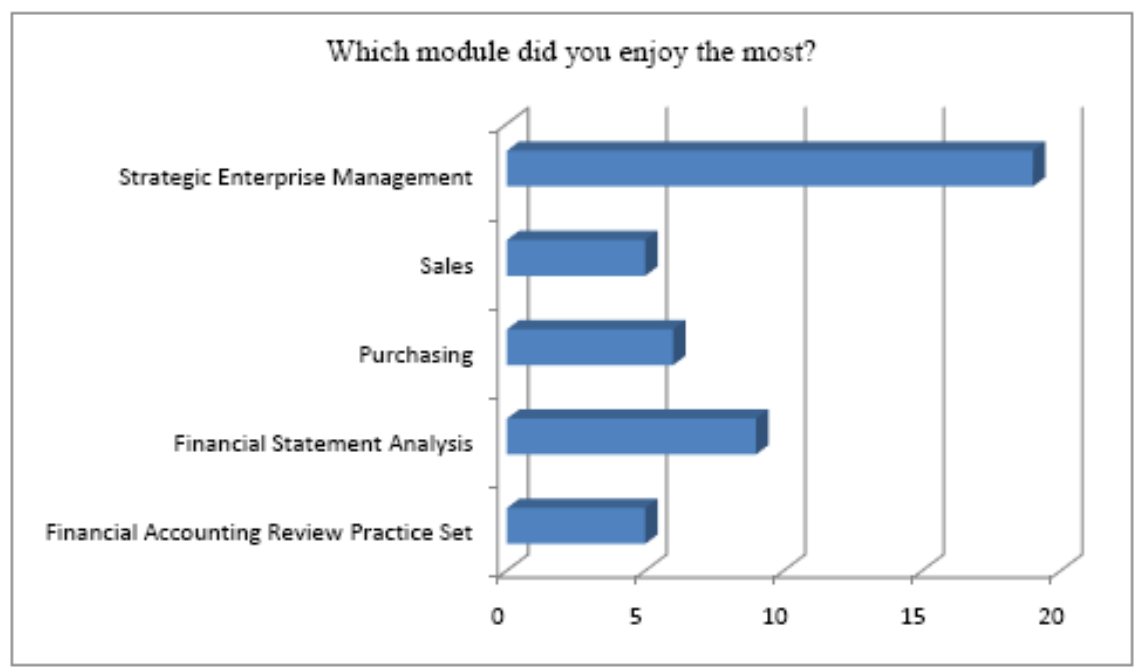

Chart 8. 


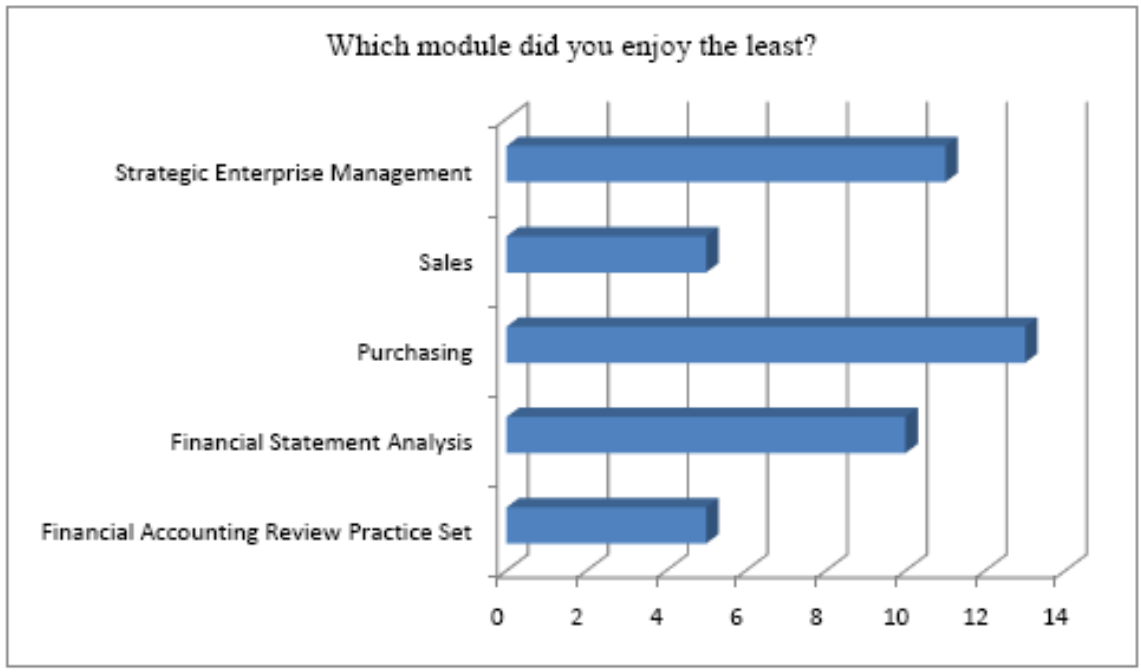

Chart 9.

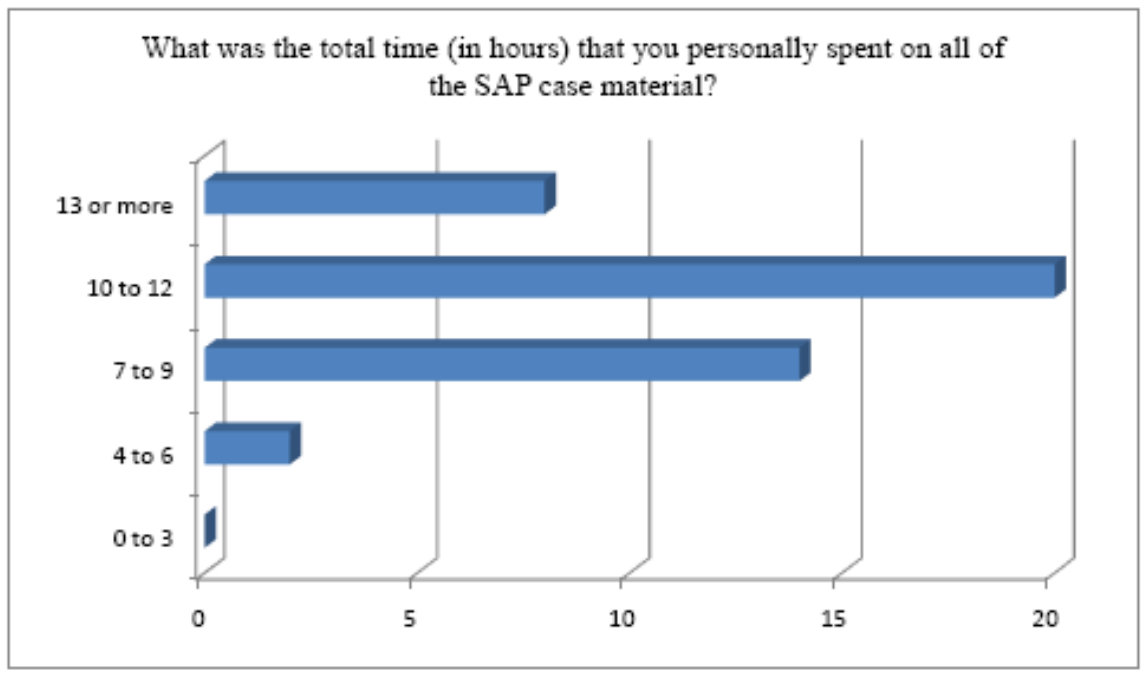

Chart 10. 


\section{STARSCHOLARS $_{\text {SIU }}$}

Are there any additional comments you would like to submit that this survey did not cover?

"I thought Module 5, the data warebouse, was by far the most interesting out of the group. I really thought it was most useful because we weren't just going through and clicking what the packet says to. In module 5, we were told what to go into, and from there we were able to be creative and give our input on bow the company looks from our perspective."

"The supplemental videos are very belpful for modules 3 through 5, especially 5 because I was not experienced with the business warehouse."

"It was belpful in not only performing the motions, but understanding the reasoning bebind them."

"Keep the S.AP program around; it is interesting and it is nice to not always bave homework that is book problems."

'I think that SAP is one of the best things to bappen to the Accounting Program at Saint Joseph's University. Not many students can leave college with a comprehensive overview of such difficult and important $R / 3$ accounting software"

Figure 1. 